\title{
NEW EVIDENCES ON THE HIPPARION SAMPLE FROM IL CASINO (SIENA, LATE MIOCENE, ITALY). PRELIMINARY REVIEW
}

\author{
Omar Cirilli1 ${ }^{1,2}$ (1) , Raymond Louis Bernor ${ }^{3,4}$ (1) \& Lorenzo Rook ${ }^{2}$ (1)
}

${ }^{1}$ Dottorato di Ricerca in Scienze della Terra, Università degli Studi di Pisa, Via S. Maria 53, I-56126 Pisa, Italy;

${ }^{2}$ Dipartimento di Scienze della Terra, Università degli Studi di Firenze 50121, Italy; lorenzo.rook@unifi.it

${ }^{3}$ College of Medicine, Department of Anatomy, Laboratory of Evolutionary Biology, Howard University, Washington D.C. 20059, USA; rbernor@howard.edu

${ }^{4}$ Human Origins Program, Department of Anthropology, National Museum of Natural History, Smithsonian Institution, Washington D.C. 20013, USA.

\section{KeYWORDS:}

Hipparion;

Il Casino;

Late Miocene;

Italy.

\section{Bullet-Points Abstract}

- Late Miocene Hipparion from Italy.

- The fossil record of Hippotherium malpassi from Central Italy.

- Hippotherium cf. malpassi from the Late Miocene of Il Casino.

\section{INTRODUCTION}

Continental Late Miocene large-vertebrate localities in Italy are mostly represented by the Baccinello-Cinigiano V3 basin (southern Tuscany), the karst cavities from the Monticino gypsum quarry (Brisighella, Emilia Romagna), the Cessaniti area (Calabria, southern Italy) and the fossil localities of Moncucco Torinese and Verduno (Piedmont, northern Italy) (Rook et al., 2006; Angelone et al., 2011; Colombero et al., 2014) but only a few of them yielded remains of Hipparionine horses. The Hipparion sample from the Baccinello V3 and from Monticino gypsum quarry have been identified as Hippotherium malpassi, a species belonging to the Hippotherium European lineage (Bernor et al., 2011; Rook and Bernor, 2013), whereas the Hipparion sample from Verduno has been ascribed to Cremohipparion cf. macedonicum. Here, two new upper cheek teeth from the Late Miocene of the
Casino basin (Siena) are discussed, in a preliminary review concerning the biogeographical implications of the Italian Hipparion record.

\section{Materials ANd Methods}

The fossil Equidae sample from the Late Miocene of "Il Casino" was collected and described at the end of the XIX century by Forsyth Major (1875) and Pantanelli (1879), which identified some few isolated upper cheek teeth and postcranial bones. The original sample is kept in the Museo di Storia Naturale di Siena, Accademia dei Fisiocritici (MSNAF) and in the Natural History Museum in London. In this contribution, the material from the MSNAF is preliminary revised, described and compared with the larger Hipparion samples from the Late Miocene Italian localities of Baccinello V3 and Monticino gypsum quarry. Anatominal nomenclature followed here is explained in Fig. 1.

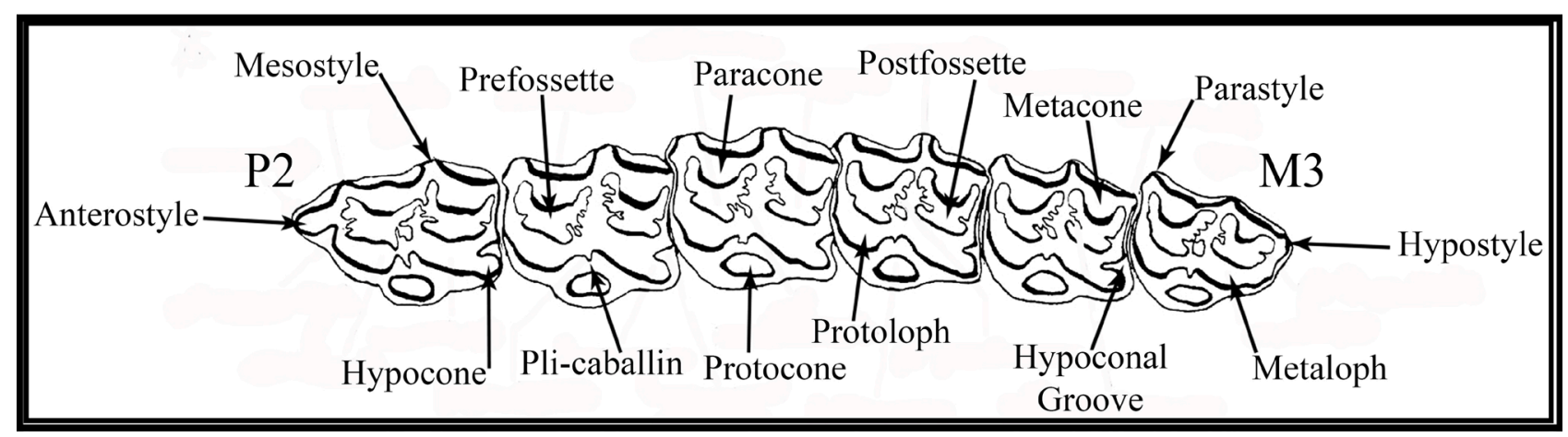

Fig. 1. Anatomical nomenclature of upper and lower dentitions in the genus Hipparion; modified from Cirilli et al. (2020).

Corresponding autor's contact: omar.cirilli@phd.unipi.it

How to cite: Cirilli et al. (2020). New Evidences on the Hipparion sample from Il Casino (Siena, Late Miocene, Italy).

Preliminary review. Fossilia, Volume 2020: 9-11. https://doi.org/10.32774/FosRepPal.2020.0603

FOSSILIA - Reports in Palaeontology 

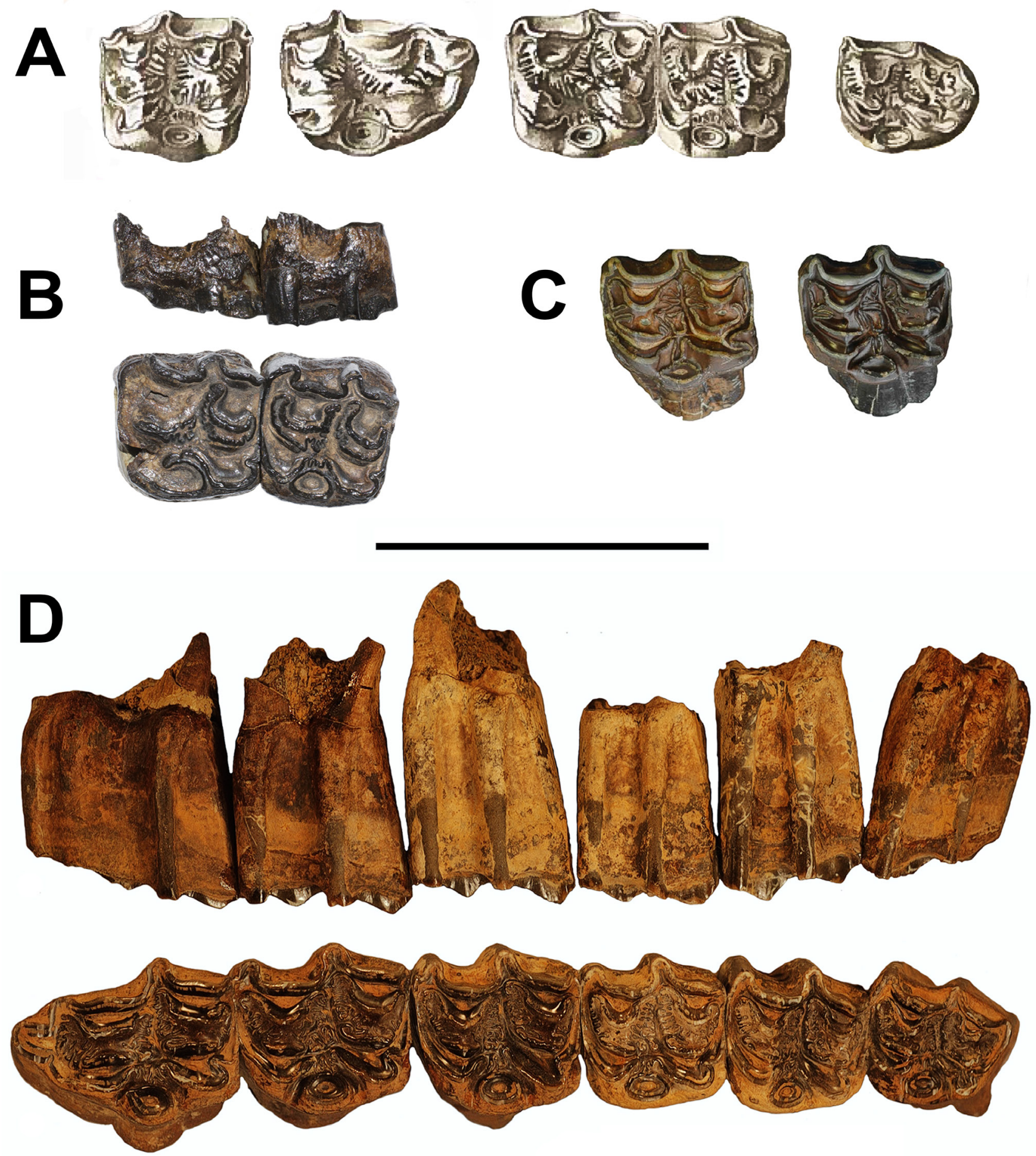

Fig. 2. A. Original Forsyth Major's drawings of the Hipparion sample from Il Casino (1875); B. MSNAF2842, upper third premolar and un upper forth premolar in labial and occlusal view (modified from Rook \& Bernor, 2013). C. Hippotherium malpassi from Monticino gypsum quarry (Brisighella, Emilia Romagna), occlusal view. D. Hippotherium malpassi from Baccinello V3 (Grosseto, Tuscany), labial and occlusal view (modified from Bernor et al., 2011). Scale bar $5 \mathrm{~cm}$. 


\section{DESCRIPTION}

Under the catalogue number MSNAF2842 (Figure 2B) the Siena museum preserves an upper third premolar and an upper forth premolar; the two teeth are in a heavy stage of wear, with the occlusal morphology of the enamel heavily worn. Nevertheless, the two specimens display a large and squared mesostyle, a high complicated morphology of the plications of pre- and post-fossettes, complex plication on the plicaballin, a round protocone and a large hypocone. These anatomical characters can be also identified in the original Forsyth Major's drawings (1875), where the occlusal morphology of the upper cheek teeth is very well preserved (Figure 2A).

\section{Discussion}

Figure 2 provides comparison of the MSNAF2842 and the original Forsyth Major's drawings from the Casino basin with the Italian Hipparion sample from Monticino gypsum quarry (Figure 2C) and Baccinello V3 (Figure 2D). The fossil Equidae assemblage from Casino shows some features which can be observed in Hippotherium malpassi from the other two Late Miocene localities, such as the plications morphology of preand post-fossettes, the plications on the pli-caballin and the protocone and hypocone shape.

Forsyth Major (1875) and Pantanelli (1879) both described this Hipparion samples ascribing the specimens to the species Hipparion gracile, albeit the authors already pointed out the complicated morphology of the enamel, which was not present on the specimens from Eppelsheim and Pikermi, used as comparison. The recentmost overview on the faunal assemblage from Il Casino (Gallai, 2005) ascribed these specimens to Hipparion sp., without any description or comparison.

\section{Conclusions}

A preliminary review on the fossil Equidae from Il Casino housed in the Museo di Storia Naturale di Siena, Accademia dei Fisiocritici, allow to identifying affinities of the upper cheek teeth morphology with Hippotherium malpassi from the Late Miocene localities of Baccinello V3 and Monticino gypsum quarry. Albeit the sample consist of just two teeth and more analysis are needed to get a better identification of the fossils specimens from Il Casino, these evidences are suggestive for a preliminary attribution to Hippotherium cf. malpassi, grounded on the several characters shared with this species. Furthermore, should this attribution will be confirmed, the occurrence of this species within the Casino fossil mammal assemblage will strength the evidence that the Casino fossil fauna shares some elements with the other Late Miocene localities of central Italy, providing new data and insights on the Late Miocene large mammal biogeography of the Mediterranean area. In this framework, a quantitative and qualitative review of the Italian Hipparion samples could allow to highlight the distribution of the species in the Late Miocene fossil record of the Italian Peninsula, which could reveal new interpretations for the European Hipparion biogeography in the Late Miocene and in the Early Pliocene.

\section{REFERENCES}

Angelone C. , Colombero S., Esu D., Giuntelli P., Marcolini F., Pavia M., Trenkwalder S., van den Hoek Ostende L., Zunino M. \& Pavia G. (2011). Moncucco Torinese, a new post-evaporitic Messinian fossiliferous site from Piedmont (NW Italy). Neues Jahrbuch für Geologie und Paläontologie Abhandlungen, 259: 89-104.

Bernor R.L., Kaiser T., Nelson S. \& Rook L. (2011). Systematics and paleobiology of Hippotherium malpassii n. sp. (Equidae, Mammalia) from the latest Miocene of Baccinello V3 (Tuscany, Italy). Bollettino della Società Paleontologica Italiana, 50: 175-208

Cirilli O., Zouhri S., El Boughabi S., Benvenuti M.G., Papini M., Bernor R.L. \& Rook L. (2020). The Hipparionine horses (Perissodactyla: Mammalia) from the Late Miocene of Tizi N'Tadderht (Southern Ouarzazate Basin; Central High Atlas; Morocco). Rivista Italiana di Paleontologia e Stratigrafia, 126 (1): 1-12.

Colombero S., Angelone C., Bonelli E., Carnevale G., Cavallo O., Delfino M., Giuntelli P., Mazza P., Pavia G., Pavia M. \& Repetto G. (2014). The Upper Messinian assemblages of fossil vertebrate remains of Verduno (NW Italy): Another brick for a latest Miocene bridge across the Mediterranean. Neues Jahrbuch für Geologie und Paläontologie, 272 (3): 287-324.

Forsyth Major C.I. (1875). Considerazioni sulla fauna dei Mammiferi pliocenici e postpliocenici della Toscana. Memorie della Società Toscana di Scienze Naturali, 1: 7-40.

Gallai G. (2005). Tafonomia e paleobiologia della fauna mammaliana turoliana (Miocene superiore) del Bacino del Casino (Siena): risultati preliminari. Rendiconti della Società Paleontologica Italiana, 2: 119-125.

Pantanelli D. (1879). Sugli strati miocenici del Casino (Siena) e considerazioni sul Miocene Superiore. Atti dell'Accademia Nazionale dei Lincei, 3: 1-21.

Rook L., Gallai G. \& Torre D. (2006). Lands and endemic mammals in the Late Miocene of Italy: constrains for paleogeographic outlines of Tyrrhenian area. Palaeogeography, Palaeoclimatology, Palaeoecology, 238: 263-269.

Rook L. \& Bernor R.L. (2013): Hippotherium malpassi (Equidae, Mammalia) from the latest Miocene (late Messinian; MN13) of Monticino gypsum quarry (Brisighella, Emilia-Romagna, Italy). Bollettino della Società Paleontologica Italiana, 52: 95-102. 
